\title{
Study the Effect of Probiotic Bacteria Isolated From Foods on Pathogens
}

\author{
Abeer Abu Zaid ${ }^{1,2} *$ \\ ${ }^{1}$ Department of Special food and nutrition, Food Technology Research Institute, \\ Agricultural Research Center, Giza, Egypt \\ ${ }^{2}$ Biology Dept., Fac. of Science, Taif University, Saudi Arabia \\ *Corresponding author
}

\begin{tabular}{|c|c|}
\hline & A B S T R A C T \\
\hline Keywords & \multirow{4}{*}{$\begin{array}{l}\text { Eleven Bacillus strains were isolated from foods and evaluated their probiotic potential } \\
\text { and safety. Then study the effect of selected strains against pathogens, and on the } \\
\text { population of pathogens in reconstituted skim milk (RSM).Seven strains from Bacillus sp. } \\
\text { (3) and Bacillus subtilis (4) were selected which were grow in low pH } 1.0 \text { to } 5.0 \text { and } \\
\text { tolerant bile salt } 0.3 \text { to } 2 \% \text {, highly resistant to simulated gastrointestinal tract conditions, } \\
\text { and showed antimicrobial activity against Salmonella typhimurium ATCC20231 and } \\
\text { Staphylococcus aureus ATCC25923. They had antibiotic susceptibility against } 6 \text { tested } \\
\text { antibiotics. Also, it's exhibited non-hemolytic on sheep blood. Two pathogens were } \\
\text { completely inhibited after } 60 \text { and } 72 \mathrm{hrs} \text { of incubation with selected probiotic strains in } \\
\text { RSM. The results indicate that Bacillus subtilis or Bacillus sp. could be used as probiotic } \\
\text { cultures for animal feeds and human, fermented vegetables, milk, meat product as well as } \\
\text { to achieve biopreservation of dairy products in food industries. }\end{array}$} \\
\hline $\begin{array}{l}\text { Probiotic strains, Bacillus } \\
\text { so., Antibacterial. } \\
\text { Antibiotic, } \\
\text { Gastrointestinal tract } \\
\text { conditions }\end{array}$ & \\
\hline Article Info & \\
\hline $\begin{array}{l}\text { Accepted: } \\
28 \text { February } 2018 \\
\text { Available Online: } \\
10 \text { July } 2018\end{array}$ & \\
\hline
\end{tabular}

\section{Introduction}

Food borne illness are major international health problems in the world wide and reduced the economic growth (WHO, 2007), although enhanced performance of effective legislative control on food processing procedures in industries. Food borne diarrheal diseases are causes of illness and death 2.2 million people annually and over than 200 types of illness transmitted by food (Mensah et al., 2002 \& Lynch et al., 2006). These pathogens are Listeria monocytogenes, Staphylococcus aureus, Escherichia coli, Salmonella typhi, Bacillus cereus, yeasts and moulds. The use of naturally produced anti- microbial agents without any adverse effects on human health to inhibit the propagation of pathogenic microorganisms in foods, that is may be challenge the problems associated with food contamination.

The expression of "probiotics" was plagiaristic from the Greek word, it is meaning as "for life" (Reid et al., 2003). After that, FAO/WHO (2006) were defined probiotics as: "Live microorganisms" which when administered in sufficient amounts confer a beneficial health to host by improving its microbial balance in gut (Aslam and Qazi, 2010). Probiotic bacteria may be producing various Anti-microbial metabolites, 
which include organic acids (lactic and acetic acids), and bacteriocins. The organic acids not only lower the $\mathrm{pH}$, but they can also be toxic to the pathogens. The beneficial of probiotic bacteria are prevention and treatment of diseases in gastrointestinal disturbances, such as dysentery, diarrhoea, typhoid (Tambekar and Bhutada, 2010).

Lactobacillus, Bifidobacterium, Lactococcus, Leuconostoc, Bacillus and many others are integrated in the list of probiotics (Isolauri et al., 2004). Probiotics are well recognized to possess specific properties such as; gastric juice and bile tolerance, adhesion to the epithelial cells of the intestine, survive in the gastrointestinal tract of humans and animals and improvement of the intestinal microbial balance (Ministry of Food and Drug Safety, 2015).

Probiotics bacteria, like common microorganisms, it may possess undesirable properties such as the advent of harmful biochemical and virulence factors. They are non-spore former, and may be destroyed in high bile concentrations of the duodenum and stomach acids. Therefore, large numbers from probiotics bacteria were require surviving in the gut anaerobic. To challenge this problem, many studies are in progress on the applicability of a new spore forming Bacilli probiotics, such as; Bacillus coagulans, Bacillus subtilis, Bacillus licheniformis, Bacillus polymyxa, and Bacillus mesentricus. They are non-pathogenic and naturally found in water and soil, ferment a large number of sugars, secrete protease, lipase and amylase enzymes, survive in the stomach and reach the intestine to germinate, and thermo stable.

Bacillus species are Gram positive bacilli, produce heat resistant spores and wide spread in environment or many types of food. B.subtilis is not harmful to mammals, including humans, and is commercially important as producer of a high fine chemicals and enzymes and diverse amount of secondary metabolites like antibiotics, as well as heterologous proteins, antigens and vaccines (Stein, 2005; Bérdy,2005 \&Valdez et al., 2014]. B.subtilis grow efficiently with low-cost carbon and nitrogen sources, because its enzymes are very efficient breaking down a great variety of proteins, carbohydrates and lipids from animal and vegetable origin, into their constituent units (Ochoa, 2012). B. subtilis spores have the ability to resist extreme $\mathrm{pH}$ conditions, UV irradiation, high temperatures, solvents and long time periods of storage without refrigeration [Sonnenschein et al., 1993]. In review, B. subtilis has adaptability of growth nutrients utilization, production high level of enzymes, secretion of antimicrobial compounds, develops in aerobic and anaerobic conditions, and B.subtilis is Generally Recognized As Safe (GRAS) by the Food and Drug Administration (FDA). Finally, B. subtilis in "theory" may be well measured as a ideal multifunctional probiotic bacterium for hosts (Cutting, 2011; Olmos et al., 2011; Sorokulova, 2013; Huang et al., 2013 \& Olmos et al., 2014).

The aim of this study to evaluate thepotential probiotics properties of Bacillus bacteria isolated from food, and their antibacterial effects against pathogenesis. Finally study the effect of co-culturing probiotic bacteria with pathogenic in skim milk.

\section{Materials and Methods}

\section{Bacterial strains}

Eleven bacterial strains (M01 -M11) were isolated under aerobic conditions from twelve traditional food products; further all strains were identified by partial 16SrRNA gene sequencing and phylogenetic analysis. All strains were identified by $97-100 \%$ identity 
including Bacillus circulans (4), Bacillus sp. (3) and Bacillus subtilis (4) according to Abu Zaid et al., (2015). Standard Biochemical tests such as gram reaction, spore former, motility, catalase reaction, oxidase activity, Esculin hydrolysis were performed following standard assessment according to (Cappuccino and Sherman, 1999).

\section{Probiotic potential}

\section{pH tolerance}

The isolates were inoculated into sterile Nutrient broth (NB) tubes of varying $\mathrm{pH}$, i.e. $1,2,3,4$, and 5 incubated at $37^{\circ} \mathrm{C}$ for 24 hours. Then $0.1 \mathrm{ml}$ inoculums from each tube was poured Nutrient agar medium by pour plate method and incubated at $37^{\circ} \mathrm{C}$ for $48 \mathrm{hrs}$. The growth of bacteria on agar was used to designate isolates as $\mathrm{pH}$ tolerant (Tambekar and Bhutada, 2010).

\section{Bile salt tolerance}

The medium with varying concentrations of bile salt $(0.3,0.5,1.0,2.0,3.0$ and $4.0 \%)$ was inoculated with each selected bacterial culture and incubated at $37^{\circ} \mathrm{C}$ for $48 \mathrm{hrs}$. Then $0.1 \mathrm{ml}$ inoculums was transferred to nutrient agar by pour plate method and incubated at $37^{\circ} \mathrm{C}$ for $48 \mathrm{hrs}$. The growth of bacteria on agar plate was used to designate isolates as bile salt tolerant (Tambekar and Bhutada, 2010).

\section{Hemolytic activity}

For testing haemolytic activity, isolates were streaked on Columbia agar plates; containing $5 \%(\mathrm{w} / \mathrm{v})$ sheep blood according to Ghrairi et al., (2008).

\section{Antibiotic susceptibility}

The selected Bacillus strains were evaluated for antibiotic susceptibility by using agar diffusion method on Mueller Hinton agar (Bauer, 1966). Antibiotics such as ampicillin (Am $10 \mathrm{U}$ ); penicillin (P $10 \mathrm{mg}$ ); nalidixic acid (NA, $30 \mu \mathrm{g})$; vancomycin (V, $30 \mu \mathrm{g}$ ); colistin $(\mathrm{CS}, 10 \mu \mathrm{g})$; tetracycline $(\mathrm{T}, 10 \mu \mathrm{g})$; Gentamicin (GM, $10 \mathrm{mg}$ ); Fusidic acid (FA, $10 \mathrm{U})$.All antibiotics were purchased from Bio-Rad, Laboratories, GmbH., Germany. Isolates culture suspension containing $\sim 10^{6} \mathrm{cfu} / \mathrm{mL}$ of the $18 \mathrm{~h}$ culture at $37^{\circ} \mathrm{C}$, then streaked on agar by a sterile cotton swab. The studied antibiotic discs were aseptically placed on the plates. The diameters of inhibition zone were calculated in $\mathrm{mm}$ under the colony counter after $24 \mathrm{hrs}$ of incubation.

\section{Effect of simulated gastrointestinal conditions}

Simulated gastrointestinal conditions were designed according to Zago et al., (2011). The growth of isolates at $\mathrm{pH} 2.0$ in the presence of $1 \%$ lysozyme, $1 \%$ trypsin, and $0.3 \%$ bile slat in Tryptic Soy Broth TSB was used to designate isolates as simulated gastrointestinal conditions.

\section{Antimicrobial activity}

For detection of antagonism activity, an agar spot test was used (Mezaini et al., 2009). Overnight cultures, on NB medium, of the strains to be tested for production of antimicrobial compound were centrifuged (10 minutes at $15000 \mathrm{~g}, \quad 4^{\circ} \mathrm{C}$ ). Cell-free supernatants were filtered across cellulose acetate filter $(0.2 \mu \mathrm{m})$ to remove residual cells. An overnight culture $\left(37^{\circ} \mathrm{C}\right)$ of the target strain was diluted in sterile MuellerHinton Medium, and $1 \mathrm{~mL}$ of $10^{6} \mathrm{CFU}$ were spread on solid Mueller-Hinton medium. The Petri dishes were dried for 10 minutes. Cork borer was used to punch one hole, $4.1 \mathrm{~mm}$ in diameter. Nutrient agar was used to seal the bottom of holes. Samples $(30 \mu \mathrm{L})$ of filtered cell-free supernatants were transferred on the 
agar plate. The target strains used in this study are Salmonella typhimurium ATCC20231, and Staphylococcus aureus ATCC25923.

\section{Effect of co-culturing probiotic bacteria with pathogenic.}

This method was used to study the effect of probiotic bacteria on the population of pathogenic in reconstituted skim milk (RSM).

A $9 \mathrm{~mL}$ of RSM was inoculated with $1 \mathrm{~mL}$ overnight culture of probiotic bacteria and 0.1 $\mathrm{mL}$ of pathogenic. Inoculated RSM medium was mixed well and incubated at $37^{\circ} \mathrm{Cfor} 0$, 12, 24, 36, 48, 60, 72 hrs. Following incubation, the population of spoilage and pathogenic bacteria was counted on nutrient agar (Denkova et al., 2013).

\section{Statistical analysis}

The data obtained from treatments were analyzed by one-way ANOVA using 'Proc Mixed' (SAS 8.2, Cary, NC, USA). In all cases, the level of statistical significance was of $\mathrm{P}<0.05$. SAS program was used to statistical analyzed (SAS 2001), LSD means comparisons were conducted with the Duncan option in SAS.

\section{Results and Discussion}

Eleven bacterial strains (M1_M11) were isolated from foods under aerobic condition characterized by biochemical conditions then identified by partial 16SrRNA gene sequencing and phylogenetic analysis by $\mathrm{Abu}$ Zaid et al., (2015). Eleven strains were identified by $97-100 \%$ identity including Bacillus circulans (4), Bacillus subtilis (4),Other isolates were identified by $85-92 \%$ identity; therefore these species are considered as new ones and named: Bacillus sp. (M07, M08, M10).Cutting, (2011) identified Bacillus strains as probiotic, they were B. subtilis, B.coagulans, B. cereus and
B. clausii. Recently, Manhar et al., (2015) was also introduced $B$. amyloliquefaciens as potential probiotics. Probiotic Bacillus strains can produce spores under insensitive conditions such as high heat, low $\mathrm{pH}$, dry, and worn out nutrients, which bacterial cells cannot stay alive, and remain viable till exposed to more good conditions. This provides many opportunities for probiotic Bacillus sp. over non-spore forming bacteria such as Lactobacillus, and Bifido bacterium strains. Spore forming probiotic Bacillus strains are widely used as nutritional supplements in humans, increase shelf life of dairy products and as growth promoters in animals and fish (Cutting, 2011). Bacillus subtilis and Bacillus sp. strains showed significant differences antimicrobial effect against two tested pathogenic strains, but Bacillus circulans strains exhibited no activity against pathogens as shown in Table 1. On the basis of maximum zone scored by M6 against Salmonella typhimurium and Staphylococcus aureus were 28 , and $25 \mathrm{~mm}$ respectively.

The same finding Patel et al., (2009) reported that, the probiotic Bacillus strain DET6 isolated from food wastes inhibited growth of Salmonella typhi and E. coli. Mahdhi et al., (2012) selected probiotic Bacillus strains had an antibacterial activity against Gram-positive and Gram-negative bacteria with diameter of the inhibition zones range between 12 and $18.6 \mathrm{~mm}$. Lee et al., (2017) isolated and identified three probiotic Bacillus strains from Korean traditional soy sauces, and showed antimicrobial activity against Bacillus cereus, Listeria monocytogenes, Staphylococcus aureus and Escherichia coli. On the other hand, B. amyloliquefaciens did not show any affect against $B$. cereus, Yersinia enterocolitica and Salmonella typhimurium, but inhibited the growth of L. monocytogenes and $K$. pneumoniae reported by Manhar et al., (2015). 
Probiotic potential of selected spore former Bacillus strains $\mathrm{pH}$ and Bile salt tolerance were shown in Table 2. In this study, Bacillus subtilis and Bacillus sp. strains were able to grow in $\mathrm{pH}$ from 1.0 to 5.0 and survive in bile salt concentrations from 0.3 to $2 \%$. Bacillus circulan strains were lost their tolerance to low acidity at pH 1.0, 2.0 and 3.0and all bile salt concentrations. On other hand, probiotic bacteria isolated from baobab (maari) fermented seeds could tolerate bile salt concentration of $0.3 \%$, and able to survive at pH 2.5 (Kabore et al., 2012). Tambekar and Bhutada (2010) isolated probiotic, which tolerance to acid ( $\mathrm{pH} 2.0)$ and bile salt at $2.0 \%$.Tolerance to bile salts is a requirement for colonization and metabolic activity of bacteria in the small intestine of the host (Havenaar et al., 1992). This will help probiotic bacteria to reach the small intestine and colon and contribute in balancing the intestinal microflora (Tambekar and Bhutada, 2010).

\section{Antibiotic susceptibility test}

The antibiotic resistances of the probiotic Bacillus strains were tested by using two groups of antibiotics categorized bytheir mechanisms. The first one were cell wall inhibitors including ampicillin, penicillin $\mathrm{G}$ and vancomycin, and second group were protein synthesis inhibitors including gentamicin and tetracycline (Argyri et al., 2013). Bacillus subtilis and Bacillus sp strains were scored multi drug resistance against 6 type of antibiotics. Antibiotic susceptibility is measured to be the best probiotic characteristic (Patel et al., 2009). In this study Bacillus subtilis and Bacillus sp strains also showedthe highest resistance to ampicillin and penicillin G. This is parallel to the reports by Manhar et al., (2015). They reported that B. amyloliquefaciens AMS1 were resistant to ampicillin and penicillin and probiotic Bacillussp.

\section{Hemolytic activity}

One of the main criteria needed to be satisfied by a probiotic organism is to be nonpathogenic (Ljungh and Wadström, 2006). In general, it can be noticed that no strain observed complete hydrolysis ( $\beta$ hemolysis) on blood sheep agar. Other isolated strains 7 out of 11 observed no hemolytic activity $(\gamma$ hemolysis). Bacillus circulan strains displayed greenish-brown color ( $\alpha$ hemolysis) around their colonies grown on blood sheep agar Table 4. This study was comparable to probiotic $B$. polyfermenticus $C J 6$, it was observed no hemolytic activity (Jung \& Chang, 2012). Probiotic Bacillus sp. BCNU9028 formed a green zone that indicates $\alpha$-hemolysis. B. cereusproduces a clear zone that indicates $\beta$-hemolysis (Jung et $a l ., 2012)$. No-hemolysis and a-hemolysis are considered to be safe and $\beta$-hemolysis was considered harmful (Shin et al., 2012). $\beta$ hemolysis is an implication that bacteria havecytotoxic phospholipases (Sorokulova et $a l ., 2008)$. The hemolytic factor decreases the amount of hemoglobin available as an iron source for the host (Seker, 2010).

To select the probiotics strains with high probiotic potential, simulate gastrointestinal conditions by identified strains were grow in the presence bile salt, lysozyme, trypsin at low $\mathrm{pH}$. If the tested strains have ability to grow under these environmental stresses, these bacterial strains can tolerant, adhere, colonize and grow after transit from the stomach to small intestinal. In the present study, all isolated strains were studied in the presence of $1.0 \%$ lysozyme, $1.0 \%$ trypsin and $0.3 \%$ bile slat at $\mathrm{pH} 2.0$. Most studied strains 7 out of 11 were could be grow under simulate gastrointestinal conditions.

In conclusion, the effect of trypsin and lysozyme might be avoided due to not fitting $\mathrm{pH}$, where these enzymes could be inactivated 
at low temperature and optimal $\mathrm{pH}$ 7.5-8.5 Barrett \& McDonald (1980). Lysozyme activity was significantly decreased at $\mathrm{pH} 6.2$ or below (Davies et al., 1969). After this explanation, the most effective factors in this simulated gastrointestinal were bile salt and $\mathrm{pH}$. As described above, the obtained results demonstrated that, bile slat and low $\mathrm{pH}$ induced adherent and biofilm formation due to increasing cell hydrophobicity (Zago et al., 2011; Ambalam et al., 2012; Nostro et al., 2012).

Experimental results, given in Fig 1, and Fig 2 , were shown that the effect of probiotic Bacillus strainson the population of pathogens in reconstituted skim milk (RSM). It depends on the variety of the pathogen as well as of the types of Bacillus probiotic strains. The agent of Salmonella was sensitive to the presence of Bacillus subtilis and Bacillus sp strains during all the period of incubation; it was complete inhibition up to the 60th hrs. Staphylococcus aureus was more resistant in the presence of Bacillus subtilis and Bacillus $s p$, it completely inhibited after 72 hrs of incubation period. Bacillus circulan strains have a similar behavior of control as shown from results and spoilage all samples after 48 hours of incubation periods. The same finding by Denkova et al., (2013) concluded that E.coli, and Salmonella were sensitive to the presence of probiotic bacteria and during joint cultivation complete inhibition up to the 60th to the 72nd hour of incubation. On the other contrasting, Staphylococcus aureus showed more resistant to the presence of probiotic bacteria in the medium, but this pathogen was sensitive to Bif. Bifidum strain only.

In conclusion, seven strains (4 Bacillus subtilis and 3 Bacillus sp.) showed no hemolytic activity ( $\gamma$ hemolysis), antibacterial activity, tolerated low $\mathrm{pH} 2.0$, bile salt up to $0.3 \%$; viable under stimulated gastrointestinal tract (SGIT) stress. These strains are strongly suggested to use as probiotics and can be measured as generally recognized as safe (GRAS) bacteria. The other four strains from Bacillus circulans have ability to incomplete hemolysis ( $\alpha$ hemolysis) and losted one of the important criteria (acid and bile tolerance). Therefore its need to advance work to assess their safety to use as probiotics. It could be concluded on the combine of different probiotic strains in order to complete the inhibition growth of bacteria and spores. As a result of the conducted studies strains of Bacillus subtilis and Bacillus sp. had high antimicrobial activity, it's important for the application of these probiotic strains in foods to extend the shelf life. Bacillus probiotics strains were used for the production of functional foods (yogurt; bioyogurt; bread with extended shelf-life; raw-dried meat products; cheeses; organic preservation of cosmetic creams).

\section{References}

Abu-Zaid, A. A. Influence of Spirulina platensis Cyanobacterium on Some pathogenic bacteria isolated from different diets. (2015). IJSR International Journal of Scientific Research. 4 (2) ISSN NO 2277-8179.

Ambalam P., Kondepudi K.K., Nilsson I., Wadström T. and Ljungh. . (2012) Bile stimulates cell surface hydrophobicity, Congo red binding and biofilm formation of Lactobacillus strains. FEMS Microbiol. Lett. $333,10-19$.

Argyri, A. A., Zoumpopoulou, G., Karatzas, K. A. G., Tsakalidou, E., Nychas, G. E.,Panagou, E. Z., et al., (2013). Selection of potential probiotic lactic acid bacteria from fermented olives by in vitro tests. Food Microbiology, 33, 282e291.

Aslam, S. and Qazi, J.I. Isolation of acidophilic lactic acidbacteria antagonistic to microbial contaminants. Pakistan Journal ofZoology, 2010; 42(5): 567-573.

Barrett A.J. and McDonald J.K. (1980) Mammalian Proteases: A Glossary and Bibliography, vol. I, Endopeptidases. London: Academic Press. 
Bauer, A.W., Kirby, W.M., Sherris, J.C. and Turck, M.(1966). Antibiotic susceptibility testing by a standardized single disk method. American Journal of ClinicaPathology, 36, 49-52.

Bérdy J. 2005. Bioactive microbial metabolites. J Antibiot (Tokyo) 58: 1-26.

CappuccinoJ.G.and Sherman N. 1999. Microiology: A Laboratory Manual,. Addison Weseley Longman, Inc Harlow.4,199-204.

Cutting SM. (2011). Bacillus probiotics. Food Microbiol 28: 214-220.

Davies R.C., Neuberger A. and Wilson B.M. (1969) The dependence of lysozyme activity on $\mathrm{pH}$ and ionic strength. Biochimica et BiophysicaActa (BBA) - Enzymology 178, 294-305.

Denkova. R.,. Denkova. Z,. Yanakieva. V., \& Blazheva. D. Antimicrobial activity of probiotic lactobacilli, bifidobacteria and propionic acid bacteria, isolated from different sources. 2013. Microbial pathogens and strategies for combating them: science, technology and education 867-864.

FAO/WHO (2006) Probiotic in foods: Health and nutritional properties andguidelines for evaluation. In FAO food and nutrition; 2005pp 85, ISBN 92-5-105513-0.

Ghrairi T., Frere J., Berjeaud J.M. and Manai M. (2008) Purification and characterisation of bacteriocins produced by Enterococcus faecium from Tunisian rigouta cheese. Food Control 19, 162-169.

Havenaar R., Brink B.T. and HuisIn't Veld J.H.J. (1992) Selection of strains for probiotics use. In Probiotics, the scientific basis, pp. 209-223 [R Fuller, editor]. London: Chappman\& Hall.

Huang Q, Xu X, Mao YL, Huang Y, Rajput IR, et al., (2013) Affects of Bacillus subtilis B10 spores on viability and biological functions of murine macrophages. AnimSci J 84: 247-252.

Isolauri, E., Salminen, S., \&Ouwehand, A. C. (2004). Probiotics. Best Practice and Research Clinical Gastroenterology, 18, $299 \mathrm{e} 313$.

Jung, J. H., \& Chang, H. C. (2012). Evaluation of the probiotic potential of Bacillus polyfermenticus CJ6 isolated from meju, a Korean soybean fermentation starter. Journal of Microbiology and Biotechnology, 22, 1510-1517.
Kabore, D., Sawadogo-Lingani, H., Dicko, M.H., Diawara, B. and Jakobsen, M. Acid resistance, bile tolerance and antimicrobial properties of dominant lactic acid bacteria isolated from traditional "maari" baobab seeds fermented condiment. African Journal ofBiotechnology. 2012; 11:1197-1206.

Lee,S; Lee, J, Jin, Y.I; Jeong J.C; Chang, Y.H; Lee, Y; Jeong, Y; \& Kim, M. Probiotic characteristics of Bacillus strains isolated from Korean traditional soy sauce LWT Food Science and Technology 79 (2017) 518524.

LjunghA. and Wadström T. (2006) Lactic acid bacteria as probiotics. Curr. Issues Intestinal Microbiol. 7, 73-90.

Lynch,M., Painter, J., Woodruf, \& Braden, C. 2006. Surveillance for foodborne disease outbreaks- United State 1998-2002.MMWR. Surveillance Summaries: Morbidity and Mortality Weekly Reported. Surveillance Summaries/DC,55,1-42.

Mahdhi, A., Kamoun, F., Messina, C., Santulli, A., \& Bakhrouf, A. (2012). Probiotic properties of Brevibacillus brevis and its influence on sea bass (Dicentrarchus labrax) larval rearing. African Journal of Microbiology Research, 6, 6487-6495.

Manhar, A. K., Saikia, D., Bashir, Y., Mech, R. K., Nath, D., Konwar, B. K., et al., (2015).In vitro evaluation of celluloytic Bacillus amyloliquefaciens AMS1 isolated from traditional fermented soybean (Churpi) as an animal probiotic. Research in Veterinary Science, 99, 149e156.

Mensah P., Yeboah-Manu D., Owusu- Darku K. and Ablordey A.(2002). Street food in Accra, Ghana: How safe are they? Bulletin of the World Health Organization.80,546-556.

Mezaini A., Chihib N.-E., Bouras A.D., NedjarArroume N. and Hornez J.P. (2009) Antibacterial Activity of Some Lactic Acid Bacteria Isolated from an Algerian Dairy Product J. Environ. Pub. Health.

Ministry of Food and Drug Safety, 2015.http://www.foodnara.go.kr/hfoodi/.Acce ssed 15.04.21.

Nostro A., Cellini L., Di Giulio M., D'Arrigo M., Marino A., Blanco A.R., Favaloro A., Cutroneo G. and Bisignano G. (2012) Effect 
of alkaline $\mathrm{pH}$ on staphylococcal biofilm formation. APMIS 120, 733-742.

Ochoa SJL, U.S. Patent 2012/0128827 A1, May 24, 2012.

Olmos J, Ochoa L, Paniagua-Michel J, Contreras $\mathrm{R}$ (2011) Functional feed assessment on Litopenaeus vannamei using $100 \%$ fish meal replacement bysoybean meal, high levels of complex carbohydrates and Bacillus probiotic strains. Mar Drugs 9: 1119-1132.

Olmos SJ, Paniagua-Michel J, Lopez L, Ochoa S L (2014) Functional feeds in aquaculture. S.K. Kim (Ed.), Handbook of Marine Biotechnology. NY: Springer, ISBN: 978-3642-53970-1, $1800 \mathrm{pp}$.

Patel, A. K., Ahire, J. J., Pawar, S. P., Chaudhari, B. L., \& Chincholkar, S. B. (2009).Comparative accounts of probiotic characteristics of Bacillus spp. isolated from food wastes. Food Research International, 42, $505 \mathrm{e} 510$.

Reid G, Hass J, Sebulsdy MT, McCormick JD (2003) Potential use of probiotics in clinical practice. Clinical. Microbiol Rev 16: 658672.

SAS., 2001. User's Guide. SAS Institute, Cary, $\mathrm{NC}$.

Seker, E. (2010). Identification of Candida species isolated from bovine mastitic milk and their in vitro hemolytic activity in Western Turkey. Mycopathologia, 169,303e308.

Shin, H. J., Choi, H. J., Kim, D. W., Ahn, C. S., Lee, Y. G., Jeong, Y. K., et al., (2012). Probiotic potential of Pediococcus pentosaceus BCNU 9070. Journal of Life Science, 22, 1194e1200.

Sonnenschein AL, Losick R, Hoch JA (1993) Bacillus subtilis and Others Gram-Positive Bacteria: Biochemistry, Physiology and
Molecular Genetics. AmericanSociety for Microbiology, Washington, DC.

Sorokulova I (2013) Modern status and perspectives of Bacillus bacteria asprobiotics. J Prob Health 1: 1-5.

Sorokulova, I. B., Pinchuk, I. V., Denayrolles, M., Osipova, I. G., Huang, J. M., Cutting, S. M., et al., (2008). The safety of two Bacillus probiotic strains for humanuse. Digestive Diseases and Sciences, 53, 954e963.

Stein T (2005). Bacillus subtilis antibiotics: structures, syntheses and specificfunctions. MolMicrobiol 56: 845-857.

Tambekar, D. H. and Bhutada, S. A.(2010). Studies on antimicrobial activity and characteristics of bacteriocins produced by Lactobacillus strains isolated from milk of domestic animals. The Internet J.Microbiol. 8:1-6.

Valdez A, Yepiz-Plascencia G, Ricca E, Olmos J (2014) First Litopenaeus vannamei WSSV $100 \%$ oral vaccination protection using CotC::Vp26 fusion protein displayed on Bacillus subtilis spores surface. J ApplMicrobiol 117: 347-357.

WHO. (2007). Food Safety and Foodborne Illness. Fact Sheet No. 237, World Health Organization. Available from http://www.who.int/mediacentre/factsheets/fs 237/en/URL (reviewed March 2007; accessed 20 November 2007.

Zago M., Fornasari M.E., Carminati D., Burns P., Suàrez V., Vinderola G., Reinheimer J. and Giraffa G. (2011) Characterization and probiotic potential of Lactobacillus plantarum strains isolated from cheeses. Food Microbiol. 28, 1033-1040.

\section{How to cite this article:}

Abeer Abu Zaid. 2018. Study the Effect of Probiotic Bacteria Isolated From Foods on Pathogens. Int.J.Curr.Microbiol.App.Sci. 7(07): 4127-4134.

doi: https://doi.org/10.20546/ijcmas.2018.707.481 